\title{
Hepatic Anisakiasis in Japan
}

Toru Shizuma*

Department of Physiology, Tokai University School of Medicine, Japan

*Corresponding author: Toru Shizuma, Department of Physiology, Tokai University School of Medicine, 143, Shimokasuya, Isehara, Kanagawa 259-1193, Japan, Tel: +81-0463-93-1121; Fax: +81-0463-93-6684; E-mail: shizuma@is.icc.u-tokai.ac.jp

Received date: August 17, 2018; Accepted date: September 03, 2018; Published date: September 05, 2018

Copyright: (C) 2018 Shizuma T. This is an open-access article distributed under the terms of the Creative Commons Attribution License, which permits unrestricted use, distribution, and reproduction in any medium, provided the original author and source are credited.

\section{Abbreviations}

CT: Computed tomography; MRI: Magnetic resonance imaging

\section{Mini Review}

Anisakis is a genus of parasitic nematodes that has lifecycles involving fish and marine mammals. Anisakiasis in humans is a fishborne parasitic disease caused by the consumption of raw or undercooked seafood infected with Anisakis larvae [1]. The prevalence of anisakiasis is estimated to be high in Northern Europe and East Asia, particularly Japan, mainly due to the popularity of Japanese cuisine, such as sushi and sashimi [1,2], despite the fact that freezing raw fish stock prevents parasitosis, such as anisakiasis [2]. Furthermore, numerous case reports on anisakiasis have been recorded in Japan compared with other countries worldwide [1]. Anisakis simplex complex is the most popular etiological agent of anisakiasis in Japan and comprises three related species, including $A$. simplex sensu stricto, which is the most common species causing anisakiasis in Japan, $A$. pegreffii, and $A$. simplex $C[3,4]$. Anisakiasis may involve any part of the digestive tract [1], and gastrointestinal anisakiasis is the most commonly occurring condition (occurrence rate, $>99 \%$ ), particularly gastric anisakiasis [1,5]. Anisakiasis commonly presents with acute abdominal symptoms caused by an allergic reaction in the gastric mucosa [2]. Although the incidence of extra-gastrointestinal anisakiasis, such as the formation of granuloma due to Anisakis infection in the lungs, omentum, peritoneum, liver, pancreas, and ovary, is uncommon [6], its incidence rate among anisakiasis cases has been reported to be $0.2 \%-0.47 \%$ in Japan [2,5,7]. Generally, medical history regarding the consumption of raw or undercooked seafood is not very important for the diagnosis of extra-gastrointestinal anisakiasis [7]; however, it may be useful for the diagnosis of gastrointestinal anisakiasis, which mainly occurs within half a day in case of gastric anisakiasis and within 1 week in case of intestinal anisakiasis following the consumption of raw or undercooked seafood [1].

Moreover, reported cases of hepatic anisakiasis presenting as liver tumor are extremely rare [5], and there are no reports on hepatic

\begin{tabular}{|c|c|c|c|c|c|c|c|c|c|}
\hline Case & $\begin{array}{l}\text { Age } \\
\text { (years) }\end{array}$ & Size $(\mathrm{mm})$ & Echogram & $\begin{array}{l}\text { Contrast- } \\
\text { enhanced CT }\end{array}$ & MRI & $\begin{array}{l}\text { Contrast-enhanced } \\
\text { MRI }\end{array}$ & $\begin{array}{l}\text { Preoperative } \\
\text { diagnosis }\end{array}$ & $\begin{array}{l}\text { Definitive } \\
\text { diagnosis }\end{array}$ & Reference \\
\hline 1 & 44 & 15 & & Low density & $\begin{array}{l}\text { High intensity } \\
\text { on DWI }\end{array}$ & & $\begin{array}{l}\text { Metastatic liver } \\
\text { tumor }\end{array}$ & $\begin{array}{l}\text { Operation } \\
\text { PCR }\end{array}$ & [2] \\
\hline 2 & 70 & 8 & & Low density & & & $\begin{array}{l}\text { Metastatic liver } \\
\text { tumor }\end{array}$ & $\begin{array}{l}\text { Operation } \\
\text { PCR }\end{array}$ & [3] \\
\hline 3 & 63 & 4 & Low-echoic & & & & & $\begin{array}{l}\text { Operation } \\
\text { PCR }\end{array}$ & [5] \\
\hline
\end{tabular}

anisakiasis in the English literature. In this study, we reviewed case reports and proceedings of hepatic anisakiasis presenting as liver tumor (or tumors) using literature searches with PubMed and Japana manuscripts, respectively. A literature search was performed using the following keywords: (1) hepatic anisakiasis; (2) extra-gastrointestinal anisakiasis; and (3) liver tumor and anisakiasis. All the 13 cases (eight case reports [2,3,5-10] and five proceedings [11-15]) have been reported in Japan, of which two cases have been reported in English $[2,6]$ and remaining 11 in Japanese [3,5,7-15].

Clinical characteristics and imaging findings of the reported 13 cases are summarized in Table 1. All cases were diagnosed as isolated hepatic anisakiasis without apparent symptoms of gastrointestinal anisakiasis. The age at diagnosis of hepatic anisakiasis ranged between 34 and 70 years, and eight patients were male [3,5-7,9,11,14,15] and five were female $[2,8,10,12,13]$. Patients were usually asymptomatic, and liver tumors were incidentally detected during imaging interventions, such as computed tomography (CT) $[3,7,9,11]$, positron emission tomography-CT [2], echography [8,12-14] (including intraoperative echography [5]), or laparoscopic examination [15]. The number of liver tumor(s) was one in 12 cases and five in one case [13]. The size of liver tumors ranged from 2 to $20 \mathrm{~mm}$; smallest liver tumor among all the cases, which was of $2 \mathrm{~mm}$, was detected by visual observation incidentally during laparoscopic examination [15], whereas the second smallest liver tumor, which was of $4 \mathrm{~mm}$, was detected incidentally during intraoperative echography at the time of surgical liver resection for another liver tumor [5]. The tumor was located in the left lobe in three cases $[2,8,10]$, right lobe in eight $[3,5,7,9,11,12,14,15]$, both the lobes in one (five tumors) [13], and at an unknown location in one [6]. In some cases, the tumor was located near the surface of the liver [5,7-10], indicating that Anisakis migrate from the surface of the liver and infiltrate the intrahepatic area near the surface of the liver after penetrating the bowel wall [5]. There have been no reports of hepatic anisakiasis in which the Anisakis species reached the liver via the portal vein from the digestive tract [5]. Centra Revuo Medicina (Igaku Chuo Zasshi) for English and Japanese 
Page 2 of 3

\begin{tabular}{|c|c|c|c|c|c|c|c|c|c|}
\hline 4 & 51 & 15 & & & & & $\begin{array}{l}\text { Metastatic liver } \\
\text { tumor }\end{array}$ & Operation & [6] \\
\hline 5 & 64 & 20 & Low-echoic & $\begin{array}{l}\text { Ring-shaped } \\
\text { enhancement }\end{array}$ & $\begin{array}{l}\text { Low intensity on } \\
\text { T1WI intensity } \\
\text { High inh } \\
\text { on T2WI }\end{array}$ & $\begin{array}{l}\text { Ring-shaped } \\
\text { enhancement, Low } \\
\text { intensity in the } \\
\text { hepatobiliary phase }\end{array}$ & Unknown & Operation & [7] \\
\hline 6 & 59 & 20 & Low-echoic & Low density & & & Unknown & Operation & [8] \\
\hline 7 & 58 & 20 & & Low density & & & $\begin{array}{l}\text { Metastatic liver } \\
\text { tumor }\end{array}$ & Operation & [9] \\
\hline 8 & 34 & 20 & & Low density & & & $\begin{array}{l}\text { Metastatic liver } \\
\text { tumor }\end{array}$ & Operation & [10] \\
\hline 9 & 60 & 10 & & Low density & & & & $\begin{array}{l}\text { Operation } \\
\text { PCR, ELISA }\end{array}$ & [11] \\
\hline 10 & 47 & 13 & & $\begin{array}{l}\text { Ring-shaped } \\
\text { enhancement }\end{array}$ & $\begin{array}{l}\text { High intensity } \\
\text { on } \mathrm{T} 2 \mathrm{WI}\end{array}$ & $\begin{array}{l}\text { Ring-shaped } \\
\text { enhancement, Low } \\
\text { intensity in the } \\
\text { hepatobiliary phase }\end{array}$ & $\begin{array}{l}\text { Metastatic liver } \\
\text { tumor }\end{array}$ & $\begin{array}{l}\text { Operation } \\
\text { ELISA }\end{array}$ & [12] \\
\hline 11 & 68 & $\begin{array}{l}7-14 \\
\text { (multiple) }\end{array}$ & Low-echoic & Low density & $\begin{array}{l}\text { Low intensity on } \\
\text { T1WI intensity } \\
\text { High inh } \\
\text { on T2WI }\end{array}$ & & & Biopsy & [13] \\
\hline 12 & 70 & Unknown & Low-echoic & & $\begin{array}{l}\text { High intensity } \\
\text { on T2WI }\end{array}$ & $\begin{array}{l}\text { Ring-shaped } \\
\text { enhancement, Low } \\
\text { intensity in the } \\
\text { hepatobiliary phase }\end{array}$ & & $\begin{array}{l}\text { Operation } \\
\text { PCR }\end{array}$ & [14] \\
\hline 13 & 62 & 2 & & & & & & $\begin{array}{l}\text { Biopsy } \\
\text { Electrophore } \\
\text { sis }\end{array}$ & [15] \\
\hline
\end{tabular}

Table 1: Clinical characteristics and imaging findings in hepatic anisakiasis cases $(n=13)$.

There have been occasional reports on the incidence of hepatic anisakiasis based on imaging findings, such as CT and magnetic resonance imaging (MRI). Liver tumors on imaging show granuloma formations with the infiltration of inflammatory cells induced by the presence of Anisakis. In five reports, the liver tumor presented as a low-echoic lesion on echogram $[5,7,8,13,14]$. It presented as a lowdensity lesion on plain CT in one report [7]. On enhanced CT, two reports indicated that the tumor presented as a ring-shaped enhancement $[7,12]$, and seven reports indicated that it presented with low-density lesion [2,3,8-11,13]. Furthermore, four reports indicated that the liver tumor was of high intensity on the T2-weighted image on MRI [7,12-14]. On contrast-enhanced MRI, three reports indicated that the tumor presented as a ring-shaped enhancement and low intensity in the hepatobiliary phase $[7,12,14]$. In all cases, precise diagnosis based on imaging findings before pathological examination was not achieved. Some reports indicated that prediagnosis of hepatic anisakiasis suggested liver metastasis $[2,3,6,9,10,12]$, partially because differential diagnosis with other benign liver tumors, such as inflammatory pseudotumor, and malignancies, such as liver metastasis or cholangiocellular carcinoma, using imaging findings was very difficult $[5,7]$.

Typical histological findings of hepatic anisakiasis include the formation of granuloma with the infiltration of eosionocytes and presence of Anisakis in the liver [2,8,11,12], inducing occasional formation of abscess [6,9], although two reports have shown that the infiltration of inflammatory cells mainly involved lymphocytes compared with eosinocytes $[3,5]$. However, the definitive diagnosis of hepatic anisakiasis may be difficult even after histological examination [2]. Other supplementary examinations for the definitive diagnosis include specific serum antibody test for Anisakis [8], enzyme immunoassay [11,12], and electrophoresis [15]. The detection of Anisakis DNA using polymerase chain reaction helps in establishing the definitive diagnosis of anisakiasis $[2,3,5,11,14]$. Among the 13 cases we reviewed, the causative agent was identified in three cases $(A$. Pegreffii $[3,5]$ in two and $A$. simplex sensu stricto [2] in one).

In conclusion, hepatic anisakiasis has been rarely reported. However, the incidence rate may be higher because many patients are asymptomatic and many physicians lack awareness, thus resulting in overlook or misdiagnosis. Moreover, it is very difficult to differentiate between hepatic anisakiasis and malignancies, such as liver metastasis or cholangiocellular carcinoma, and may result in unnecessary resection in case of hepatic anisakiasis. Therefore, physicians must consider hepatic anisakiasis as a differential diagnosis of liver tumor despite its rare incidence even in countries where anisakiasis is hyperendemic.

\section{References}

1. Tsukui M, Morimoto N, Kurata H, Sunada F (2016) Asymptomatic anisakiasis of the colon incidentally diagnosed and treated during colonoscopy by retroflexion in the ascending colon. J Rural Med 11: 73-75. 
2. Nogami Y, Fujii-Nishimura Y, Banno K, Suzuki A, Susumu N, et al. (2016) Anisakiasis mimics cancer recurrence: two cases of extragastrointestinal anisakiasis suspected to be recurrence of gynecological cancer on PET-CT and molecular biological investigation. BMC Med Imaging 16: 31.

3. Hayshi R, Sugai K, Yang H, Satoh T, Abo A, et al. (2015) A case of liver anisakiasis found out in the follow-up period after operation of the rectal cancer. Clin Parasitol 26: 20-23.

4. Umehara A, Kawakami Y, Araki J, Uchida A (2007) Molecular identification of the etiological agent of the human anisakiasis in Japan. Parasitol Int 56: 211-215.

5. Sekoguchi S, Nagao Y, Takemura K, Yamaguchi K, Dainaka K, et al. (2016) A case of hepatic anisakiasis. Kanzo 57: 577-585.

6. Kagei N, Orikasa H, Hori E, Sannomiya A, Yasumura Y (1995) A case of hepatic anisakiasis with a literal survey for extra-gastrointestinal anisakiasis. Jpn J Parasitol 44: 346-351.

7. Ishida M, Sano S, Terada T, Mitsui T, Sudoh Y, et al. (2013) A case of hepatic anisakiasis. J Jpn Surg Assoc 74: 2557-2561.

8. Morita M, Soyama A, Takatsuki M, Kuroki T, Abe K, et al. (2013) A case of hepatic mass induced by extra-gastrointestinal anisakiasis. J Jpn Surg Assoc 74: 483-487.

9. Kawakami S, Ikeda E, Naito M, Yamada M, Tsuji H, et al. (1995) A case report of hepatic abscess induced by anisakiasis. The Okayama Red Cross Hospital journal of medicine 6: 92-96.
10. Kunitomi M, Sugiura Y, Yoshizumi Y, Morisaki Y, Koike H, et al. (1996) A case of anisakiasis simultaneously parasitized in the gastric paries and the liver. The Journal of the Saitama Medical Society 30: 968-971.

11. Yamaguchi A, Maeda S, Hama N, Miyamoto A, Uemura M, et al. (2017) A case of hepatic anisakiasis. The Journal of Japan Society for Surgical Infection 14: 553.

12. Okada T, Kawai A, Mineta S, Okamoto Y, Uraoka M, et al. (2017) A case of hepatic anisakiasis. J Jpn Surg Assoc 78 Suppl: 574.

13. Ideguchi S, Ohashi K, Fukushima K, Kita S (2002) A case of hepatic anisakiasis detected using provincial ultrasonic examination. J Gastrointestinal Cancer Screen 40: 301.

14. Inamori O, Konishi E, Kawakami K, Yamada M, Yanagisawa A (2016) A case report of extra-gastrointestinal anisakiasis resected as a hepatic tumor. Proceedings of the Japanese Society of Patholog 105: 450.

15. Ueki K, Hirakawa H, Yoshioka N, Shimada N (1989) A case of hepatic anisakiasis detected as a specific discolored area on the liver surface and white nodule in the liver on laparoscopic examination. Gastroenterol Endosc 31: 231 . 